\title{
Perbandingan Zat Besi dengan dan Tanpa Vitamin C terhadap Kadar Hemoglobin Wanita Usia Subur
}

\author{
Comparison Effect of Iron with and without Vitamin C to Age Hemoglobin \\ Levels among Women of Reproductive Age
}

Tuti Anggriani Utama, Nora Listiana, Desi Susanti

Program Studi Ilmu Keperawatan Fakultas Ilmu Kesehatan Universitas Muhammadiyah Bengkulu

\begin{abstract}
Abstrak
Anemia pada wanita pekerja masih merupakan masalah kesehatan yang dapat menurunkan produktivitas kerja. Penelitian ini bertujuan untuk membandingkan zat besi dengan dan tanpa vitamin $\mathrm{C}$ terhadap kadar hemoglobin. Jenis penelitian yang digunakan yaitu Quasy Experimental dengan Pre Test and Post Test Control Group Design. Populasi penelitian berjumlah 600 orang dan sampel berjumlah 60 orang. Teknik pengambilan sampel random sampling. Pengumpulan data dilakukan dengan cara pengamatan, wawancara, pemeriksaan hemoglobin, dan data sekunder. Pada kelompok perlakuan diberi tablet zat besi dan dVitamin C, pada kelompok kontrol hanya diberi tablet zat besi. Intervensi yang dilakukan adalah pemberian tablet zat besi dengan dan tanpa vitamin $\mathrm{C}$, satu kapsul perminggu.Nilai rata-rata kadar hemoglobin pada kelompok kontrol pada sebelum intervensi yaitu 9,15 gram/dL dan setelah intervensi meningkat menjadi 10,19 gram/dL. Pada kelompok perlakuan rata-rata kadar hemoglobin sebelum intervensi sebesar $9,5 \mathrm{gram} / \mathrm{dL}$ dan meningkat menjadi $11,44 \mathrm{gram} / \mathrm{dL}$ sesudah intervensi. Hasil uji T berpasangan menunjukkan perbedaan yang signifikan pada nilai mean kadar hemoglobin pada kelompok kontrol dan perlakuan (nilai $p=0,000$ ). Penelitian ini diharapkan dapat digunakan sebagai salah satu masukan perencanaan dan evaluasi program gizi yang dapat dilakukan dalam rangka meningkatkan pola hidup sehat wanita pekerja di PT Sarana Mandiri Mukti Kepahiang.
\end{abstract}

Kata kunci: Anemia, program intervensi vitamin C, tingkat hemoglobin, zat besi

\footnotetext{
Abstract

Anemia in women workers, remains a health problem that can reduce work productivity. The study aimed to compare iron with and without vitamin $C$ to hemoglobin levels. Quasy experimental research was conducted with pre test and post test control group design. Study population were of 600 people and 60 people as sample with random sampling technique. Data was collected through observations, interviews, examination of hemoglobin
}

and secondary data. In the treatment group were given iron and plus Vitamin C, in the control group were given only iron. Intervention is the provision of iron with and without vitamin $C$, one capsule a week.Mean of hemoglobin level in control group before intervention was $9.15 \mathrm{gram} / \mathrm{dL}$ increased to $10.19 \mathrm{gram} / \mathrm{dL}$ in after intervention. Treatment group also show increasing hemoglobin level mean before and after intervention from 9.5 $\mathrm{gram} / \mathrm{dL}$ to $11.44 \mathrm{gram} / \mathrm{dL}$. Paired T test revealed significant differences between control and treatment group ( $p$ value $=0.000$ ). It is hoped this research can be used as one input and evaluation of nutrition programs planning to do in order to improve healthy lifestyles of women workers at PT Sarana Mandiri Mukti Kapahiang.

Keywords: Anemia, vitamin C intervention program, hemoglobin levels, iron

\section{Pendahuluan}

Kejadian anemia pada wanita usia subur masih merupakan masalah kesehatan masyarakat terbesar di dunia. Di Amerika, sekitar 12\% wanita usia subur usia $15-49$ tahun, dan $11 \%$ wanita hamil usia subur mengalami anemia. Di Indonesia, prevalensi dikalangan remaja adalah $57,1 \%$, wanita usia subur $(27,9 \%)$ dan ibu hamil $(40,1 \%){ }^{1}$ Penyebab utama anemia gizi di Indonesia adalah asupan zat besi (Fe) yang rendah. Anemia gizi besi dapat menyebabkan penurunan kemampuan fisik, produktivitas kerja, dan kemampuan berpikir. Selain itu, anemia gizi juga dapat menyebabkan penurunan antibodi sehingga mudah sakit karena terserang infeksi dan dapat menimbulkan kelelahan, badan lemah, penurunan

Alamat Korespondensi: Tuti Anggriani Utama, Prodi Ilmu Keperawatan Fakultas Ilmu Kesehatan Universitas Muhammadiyah, Jl. Salak Raya Lingkar Timur Bengkulu 38229, Hp.0852668212411,e-mail: tuti_utama@yahoo.co.id 
kapasitas/kemampuan atau produktivitas kerja. Wanita usia subur adalah salah satu kelompok risiko tinggi untuk menderita anemia karena tidak mempunyai asupan dan cadangan zat besi yang cukup terhadap kebutuhan dan kehilangan zat besi. Apapun penyebabnya, defisiensi zat besi terjadi secara perlahan yang pada akhirnya defisiensi tersebut menimbulkan dampak pada $\mathrm{Hb}$, mioglobin, dan senyawa zat besi lain. ${ }^{1}$ Absorpsi zat besi nonheme dapat ditingkatkan apabila terdapat kadar vitamin C yang cukup. ${ }^{2}$

Berdasarkan survei awal yang dilakukan peneliti pada bulan Maret tahun 2012 didapatkan informasi dari 30 orang ibu yang sedang istirahat sebanyak 20 ibu mengeluh badan cepat lelah, lemah, letih, lesu, terkadang merasa kepala pusing terutama ketika menstruasi, misalnya memetik teh mereka tidak bertenaga dan semangat, sehingga pengumpulan teh menjadi lama. Sepuluh orang ibu mengatakan meskipun sudah sarapan di rumah tetapi masih merasakan kelelahan. Wawancara dengan salah satu mandor diperoleh informasi bahwa dalam satu hektar perkebunan pekerjanya berjumlah 25 orang, sedangkan luas perkebunan teh 24 hektar. Namun, perusahaan belum pernah melakukan pemeriksaan kadar $\mathrm{Hb}$ maupun pemberian tambah darah seperti tablet zat besi. Apabila pekerja sakit, mereka akan berobat ke Puskesmas Kabawetan yang secara administrasi ditanggung oleh perusahaan. Penelitian ini bertujuan untuk mengetahui perbandingan pemberian zat besi dengan dan tanpa vitamin C terhadap kadar hemoglobin wanita di PT Sarana Mandiri Mukti Kepahiang tahun 2012.

\section{Metode}

Penelitian ini menggunakan desain quasy experimental dengan pre test and post test control group design. Populasi penelitian berjumlah 600 orang. Besar sampel dalam penelitian ini adalah seluruh wanita usia subur yang berjumlah 60 orang yang anemia. Dari 60 orang yang diperoleh dibagi menjadi 2 kriteria yaitu 30 orang diberikan vitamin $\mathrm{C}$ dan 30 tidak diberikan vitamin $\mathrm{C}$. Kriteria inklusi meliputi wanita usia subur $(15-45$ tahun), tidak dalam keadaan sakit berat dan hamil, bersedia menjadi responden. Kriteria eksklusi meliputi pekerja wanita yang anemia berat (kadar hemoglobin $<8 \mathrm{gram} / \mathrm{dL}$ ). Pengambilan sampel menggunakan teknik random.

Pengumpulan data dilakukan dengan cara pengamatan, wawancara, pemeriksaan hemoglobin dan data sekunder. Pada kelompok kontrol, hanya diberi zat besi (200 mg ferro sulfat) (kelompok I). Pada kelompok perlakuan, diberi zat besi (200 $\mathrm{mg}$ ferro sulfat) dan vitamin C (100 mg) (kelompok 2). Pemberian zat besi dan vitamin $\mathrm{C}$ diberikan 1 tablet per minggu dan 1 tablet selama 10 hari (waktu menstruasi). Total waktu pemberian selama 12 minggu. Penelitian ini menggu- nakan sumber data primer yaitu data yang diperoleh langsung dari responden penelitian yang mendapat tablet tambah darah dengan dan tanpa vitamin $\mathrm{C}$ dan melakukan pemeriksaan langsung ke responden metode pengukuran kadar hemoglobin adalah cyanmethemoglobin yang dilakukan sebelum dan sesudah intervensi.

Pengambilan darah dilakukan menggunakan lancet melalui darah tepi yang ditampung pada tabung yang telah berisi larutan Ethyl Diamine Tetra Aceticacid (EDTA) untuk menghindari pembekuan darah. Selanjutnya, hasil tersebut dibawa ke laboratorium Puskesmas Kepahiang. Pengukuran kadar hemoglobin tersebut membutuhkan 20 mikron sampel yang ditambah $415 \mathrm{ml}$ reagen Drabkin (NaHCO 31 gram, KCN $50 \mathrm{mg}$ dan $\mathrm{K} 3 \mathrm{FeCN} 200 \mathrm{mg}$ ). Setelah itu, darah diinkubasi selama 5 menit pada suhu $37^{\circ} \mathrm{C}$ dan hasil dibaca dengan menggunakan alat spectrophotometry pada gelombang tertentu $(\mathrm{a}=546 \mathrm{~nm})$. Spektofotometer yang digunakan adalah photometer 4010 Mannheim Boehringer dengan ketelitian $0,01 \mathrm{mg} / \mathrm{dL}$. Pengukuran kadar hemoglobin dilakukan oleh peneliti dibantu oleh analis kesehatan. Analisis data dilakukan dengan menggunakan analisis univariat, dan bivariat untuk perbedaan kadar hemoglobin yang dinilai dengan uji $\mathrm{T}$ paired samples test dengan tingkat signifikansi a $=0,05.3,4$

\section{Hasil}

Pada kelompok kontrol hanya mendapatkan tablet zat besi; kelompok perlakuan mendapatkan tablet zat besi dan vitamin C. Rerata kadar hemoglobin sebelum intervensi pada kelompok kontrol adalah 9,15 gram/dL, standar deviasi 0,9698 gram/dl, sesudah intervensi rerata kadar hemoglobin meningkat menjadi 10,64 gram/dL, standar deviasi yaitu 1,4892 gram/dL. Pada kelompok perlakuan sebelum intervensi rerata kadar hemoglobin yaitu 9,50 gram/dL, standar deviasi 1,0501 gram/dL dan sesudah intervensi meningkat menjadi 11,44 gram/dL dengan standar deviasi 1,2162 gram/dL. Perbandingan selisih kadar hemoglobin sebelum dan sesudah pada masing-masing kelompok yaitu 1,54 gram/dL pada kelompok kontrol dan 1,94 gram/dL pada kelompok perlakuan (Tabel 1).

Tabel 1. Perbandingan Rerata Kadar Hemoglobin pada Kelompok Kontrol dan Perlakuan Sebelum dan Sesudah Intervensi

\begin{tabular}{lcccc}
\hline Kelompok & Mean & SD & Delta & Nilai p \\
\hline $\begin{array}{l}\text { Kontrol (n = 30) } \\
\quad \text { Sebelum }\end{array}$ & 9,15 & 0,9698 & 1,54 & 0,000 \\
$\quad \begin{array}{l}\text { Sesudah } \\
\text { Perlakuan }(\mathbf{n}=\mathbf{3 0})\end{array}$ & 10,69 & 1,4892 & & \\
$\quad$ & & & & \\
$\quad$ Sebelum & 9,50 & 1,0501 & 1,94 & 0,000 \\
$\quad$ Sesudah & 11,44 & 1,2162 & & \\
\hline
\end{tabular}


Tabel 2. Perubahan Rerata Sebelum dan Sesudah Intervensi Fe pada Masingmasing Kelompok Perlakuan

\begin{tabular}{lccccc}
\hline Kelompok & Mean & SD & SE & 95\% CI & Nilai p \\
\hline Kontrol & $-1,5473$ & 0,8848 & 0,1615 & $-1,8777-1.2169$ & 0,000 \\
Perlakuan & $-1,9370$ & 0,7535 & 0,1376 & $-2,2184-1.6556$ & 0,000
\end{tabular}

Tabel 2 menunjukkan bahwa peningkatan kadar hemoglobin antara kelompok pemberian zat besi pada kelompok kontrol dan pemberian zat besi dan vitamin C pada kelompok perlakuan terlihat adanya perbedaan. Peningkatan kadar hemoglobin kelompok II lebih tinggi dari kelompok I. Hal ini terlihat pula pada hasil uji $\mathrm{t}$ paired samples test diperoleh nilai $\mathrm{p}=0,000$, artinya adanya perbandingan pemberian zat besi dan atau vitamin C terhadap kadar hemoglobin wanita usia subur di PT Sarana Mandiri Mukti Kepahiang (Tabel 2).

\section{Pembahasan}

Hasil penelitian menunjukkan rerata kadar hemoglobin sebelum intervensi pada wanita usia subur adalah 9,15 gram/dL. Kekurangan hemoglobin akan menyebabkan kekurangan oksigenasi sel sehingga proses metabolisme menurun dan fungsi sel tidak optimal sehingga daya serap makanan kurang dan bisa menyebabkan penurunan nafsu makan. Hal tersebut dapat dipengaruhi oleh beberapa faktor meliputi asupan makanan, pola makan. Kadar hemoglobin yang rendah dapat disebabkan oleh efisiensi besi, defisiensi asam folat dan vitamin B12 atau karena penyakit kronis. Di samping itu, kemungkinan juga disebabkan meta-bolisme besi, asam folat dan vitamin B12 serta interaksinya dalam tubuh. Besi berinteraksi dengan vitamin B12 dapat meningkatkan metabolisme, tetapi logam kobalt dalam vitamin $\mathrm{B} 12$ berinterasi dengan besi menurunkan absorpsi sehingga menyebabkan perbedaan tidak bermakna. Vitamin B12 membantu metabolisme asam folat yang dapat meningkatkan metabolisme besi dalam tubuh. Hasil penelitian ini sesuai dengan hasil penelitian terdahulu bahwa pemberian zat besi merupakan suplementasi yang dapat diberikan pada penderita anemia. $5-6$

Zat gizi lain yang dapat menurunkan absorpsi besi antara lain mangan dan tembaga, sedangkan zat gizi mikro dapat meningkatkan absorpsi vitamin B12.7 Informasi dari penelitian di Malawi dan Nepal sebagai negara berkembang memperlihatkan bahwa defisiensi besi tidak selalu menjadi penyebab dominan anemia. Di Malawi, defisiensi besi pada wanita usia subur ditemukan 55,3\% sedangkan di Nepal 55,6\% ${ }^{8}$ Penelitian di Bangladesh menemukan anemia pada pekerja tidak hanya disebabkan oleh defisiensi besi tetapi juga defisiensi asam folat dan vitamin A. ${ }^{9}$ Salah satu upaya meningkatkan kadar hemoglobin adalah pemberian tablet tambah darah. Kadar hemoglobin sangat memengaruhi produktivitas kerja, dengan peningkatan kadar hemoglobin darah dapat memengaruhi peningkatan produktivitas kerja. Faktor yang memperberat anemia antara lain adanya zat inhibitor eritropoesis, perdarahan akibat trombopati, anemia hemolitik akibat mikroangiopati, kehilangan darah akibat pengambilan darah untuk pemeriksaan laboratorium atau darah yang terperangkap atau tertinggal di alat HD.

Ada peningkatan rerata kadar hemoglobin pekerja yang diberikan tablet tambah darah dan atau vitamin $\mathrm{C}$ karena kepatuhan responden minum tablet zat besi yang diberikan secara teratur. Pemberian zat besi dan vitamin C menyebabkan peningkatan kadar hemoglobin lebih tinggi dari pemberian zat besi saja. Namun, ada juga subjek yang mengalami perubahan kadar hemoglobin, tetapi belum mencapai nilai kadar hemoglobin normal (12 gram/dL). Hal tersebut dapat terjadi antara lain karena kesulitan mengingat aturan minum obat setiap hari, keterbatasan dana untuk membeli suplemen secara teratur. Peningkatan Kadar hemoglobin setelah pemberian suplementasi zat besi adalah sekitar 2,15 gram/dL dan pemberian suplementasi berpengaruh terhadap peningkatan kadar hemoglobin pada pekerja wanita (nilai $\mathrm{p}$ $=0,000) .{ }^{10}$ Kekurangan zat-zat besi dalam makanan berdampak gangguan kesehatan dan penurunan produktivitas kerja. ${ }^{11}$ Pada wanita dewasa, anemia akan menurunkan daya tahan tubuh sehingga mudah sakit dan menurunkan produktivitas kerja. Bagi remaja putri, anemia dapat menurunkan kemampuan dan konsentrasi belajar, menggangu pertumbuhan sehingga tinggi badan tidak mencapai optimal, menurunkan kemampuan fisik olahraga, mengakibatkan muka pucat.

Pencegahan dan pengobatan anemia meliputi pemberian suplementasi tablet besi, pendidikan dan upaya yang ada kaitanya dengan peningkatan asupan zat besi melalui makanan, pengawasan penyakit infeksi pengobatan yang efektif dan tepat waktu dapat mengurangi dampak gizi yang tidak diinginkan, mendidik keluarga penderita tentang cara makan yang sehat selama dan sesudah sakit, fortifikasi makanan yang banyak dikonsumsi dan diproses secara terpusat merupakan inti pengawasan anemia di berbagai negara. Zat besi mempunyai fungsi penting di dalam tubuh antara lain sebagai media transportasi bagi oksigen dari paru-paru ke berbagai jaringan tubuh serta juga akan berfungsi sebagai katalis dalam proses perpindahan energi di dalam sel, produksi komponen pembawa oksigen yaitu hemoglobin dan mioglobin. ${ }^{10}$ Temuan ini sesuai dengan penelitian lainya bahwa semakin tua umur seseorang, semakin berkurang kadar hemoglobin. Dengan bertambahnya umur dan penurunan status kesehatan, terjadi penurunan fungsi dari berbagai organ. 12

Hemoglobin terdapat di dalam sel darah merah dan 
merupakan protein yang berfungsi untuk untuk mengangkut oksigen ke berbagai jaringan tubuh sedangkan mioglobin terdapat di dalam sel otot dan berfungsi untuk menyimpan dan mendistribusikan oksigen ke dalam selsel otot. Selain berfungsi memproduksi hemoglobin dan mioglobin, zat besi juga dapat tersimpan di dalam protein feritin, hemosidirin di dalam hati dan sumsum tulang belakang. Sebagai indikator level jumlah zat besi di dalam tubuh, feritin yang bersirkulasi di dalam darah dapat digunakan untuk menilai status zat besi di dalam tubuh. Penyerapan besi dipengaruhi oleh banyak faktor, proteinhewani dan vitamin $\mathrm{C}$ meningkatkan penyerapan. Kopi, teh, garam kalsium, magnesium dapat mengikat zat besi sehingga mengurangi jumlah serapan. Sebaiknya, tablet zat besi ditelan bersamaan dengan makanan yang dapat memperbanyak jumlah serapan, sementara makanan yang mengikat zat besi sebaiknya dihindarkan atau tidak dimakan dalam waktu bersamaan. Di samping itu, penting pula diingat, tambahan besi sebaiknya diperoleh dari makanan karena tablet zat besi terbukti dapat menurunkan kadar seng dalam serum.

Rerata kadar hemoglobin pada pengukuran sebelum dan sesudah pemberian zat besi dan vitamin $\mathrm{C}$ ada peningkatan. Hal ini dapat dipengaruhi oleh pemberian tablet tambah darah yang berfungsi menambah kadar hemoglobin dalam tubuh dan asupan vitamin $C$ yang diminum secara teratur setiap minggu. Pemberian tablet tambah darah dalam jangka 12 minggu dapat meningkatkan kadar hemoglobin darah. Penderita dengan hemoglobin rendah yang diberi suplementasi zat besi menunjukkan perbaikan yang bermakna terhadap peningkatan kadar hemoglobin dan produktivitas kerja. ${ }^{13}$ Penanggulangan anemia terutama pada wanita pekerja sudah dilakukan secara nasional dengan pemberian pil zat besi selama 3 bulan yang diminum setiap hari. Suplementasi zat besi menjadi salah satu cara untuk meningkatkan hemoglobin darah dan kesehatan wanita pekerja. Zat besi di dalam bahan makanan dapat berbentuk hem yang berikatan dengan protein dan terdapat dalam bahan makanan yang berasal dari hewani. ${ }^{14}$ Lebih dari 35\% hem ini dapat diabsorpsi langsung. Bentuk lain adalah dalam bentuk nonhem yaitu senyawa besi anorganik yang kompleks yang terdapat di dalam bahan makanan yang berasal dari nabati, yang hanya dapat diabsorbsi sebanyak $5 \%$. Pemberian zat besi secara oral dapat menimbulkan efek samping pada saluran gastrointestinal pada sebagian orang, seperti rasa tidak enak di ulu hati, mual, muntah dan diare. Frekuensi efek samping ini berkaitan langsung dengan dosis zat besi. ${ }^{15}$ Tidak tergantung senyawa zat besi yang digunakan dan tidak satupun senyawa yang ditolelir lebih baik daripada senyawa yang lain. Zat besi yang dimakan bersama dengan makanan akan ditolelir lebih baik meskipun jumlah zat besi yang diserap berkurang. ${ }^{16}$ Penyebab anemia sekarang tidak hanya defisiensi zat besi tetapi juga defisiensi zat gizi mikro yang lain seperti asam folat, vitamin B12, B2, B6, mangan dan tembaga.

Pada penelitian di Bangladesh, diketahui bahwa suplementasi zat besi dan asam folat dapat meningkatkan kadar hemoglobin pada wanita pekerja. ${ }^{5}$ Vitamin C dapat berperan meningkatkan absorbsi zat besi nonheme menjadi empat kali lipat. Vitamin C dan zat besi membentuk senyawa askorbat besi kompleks yang mudah larut dan mudah diabsorbsi. ${ }^{16}$ Penelitian terdahulu juga mengindikasikan bahwa ada hubungan yang bermakna antara peningkatan kadar hemoglobin dengan konsumsi vitamin C, zat besi nonheme akan meningkat $2-20 \%$ bila mengkonsumsi vitamin C. ${ }^{5}$ Vitamin C terdapat tersebar di dalam berbagai jaringan dalam urutan konsentrasi yang semakin menurun ialah jaringan retina, pituilary gland, corpus luteum, adrenal cortex, thymus, hati, otak, testis, ovarium, dan sebagainya. Kadar vitamin C di dalam jaringan tubuh dan di dalam darah yang dianggap normal ialah $0,8-10 \mathrm{mg} \% .{ }^{17,18}$ Kebutuhan akan vitamin $\mathrm{C}$ bagi tiap individu berbeda, jelasnya sebagai berikut: pada bayi diperkirakan sekitar $30 \mathrm{mg}$ per hari, pada anak-anak, sekitar $60 \mathrm{mg}$ per hari, pada usia pertumbuhan, sekitar $90 \mathrm{mg}$ per hari, pada orang dewasa, sekitar $75 \mathrm{mg}$ per hari, pada wanita hamil, sekitar 100 mg per hari, pada wanita/ibu yang menyusui, sekitar 150 mg per hari.

\section{Kesimpulan}

Prevalensi kadar hemoglobin yang kurang dari normal sebelum intervensi zat besi masih cukup tinggi rerata $9,15 \mathrm{~g} / \mathrm{dL}$ pada kelompok I dan setelah intervensi rerata meningkat yaitu 10,69 g/dL. Sedangkan pada kelompok perlakuan sebelum intervensi zat besi dan vitamin C rerata 9,50 g/dl dan setelah intervensi 11,44 gram/dL. Selisih peningkatan pada kelompok kontrol yaitu1,55 gram/dL dan kelompok perlakuan yaitu 1,94 gram/dL. Secara statistik ada peningkatan kadar hemoglobin kelompok kontrol dan kelompok perlakuan dengan nilai $\mathrm{p}=0,000$.

\section{Saran}

Bagi pihak PT Sarana Mukti dapat melakukan pemeriksaan kadar hemoglobin bagi pekerja wanita setiap bulan, pemberian zat besi untuk pekerja yang anemia dan tambahan vitamin C. Di samping itu, diperlukan penyuluhan pada pekerja wanita agar dapat meningkatkan pengetahuan tentang anemia dan gizi sehingga dapat memilih bahan makanan yang bergizi guna peningkatan asupan zat gizi dan kadar $\mathrm{Hb}$ wanita pekerja.

\section{Daftar Pustaka}

1. Ramakrishnan U, Gonzales TC, Neufeld LM, Rivera J, Martorell R. Multiple micronutrient supplementation during pregnancy does not lead 
to greater infant birth size than does iron only supplementation a randomized controlled trial in a semirural community in Mexico. American Journal of Clinical Nutrition. 2003; 77: 720-5.

2. Robbins. Buku ajar patologi. 7th ed. Jakarta: EGC; 2007.

3. Mulyawati. Efek sumplementasi, asam folat dan vitamin B12 di perusahaan plywood Jakarta [diakses tanggal 12 Februari 2012]. Available from: http;//eprints.undip.ac.id/18331/1. 2009. 31Januari 2009.

4. Chandra B. Metodologi penelitian kesehatan. Jakarta: EGC; 2008.

5. Untari R. Anemia dan kelelahan kerja pada wanita yang bekerja di malam hari [Internet]. Jurnal Lembaga Pengabdian Kepada MasyarakatUGM. 2004 [diakses tanggal 17 Februari 2012]. Available from: http:// ummusaudahbelajargizi.blogspot.com.

6. Riyanto. Pengaruh pemberian sirup besi, vitamin $\mathrm{C}$ dan vitamin $\mathrm{A}$ terhadap kadar hemoglobin balita dengan anemia di Kabupaten Buleleng. Data Base Jurnal Indonesia. 2009; 5: 12-6.

7. Groff JL, Gropper SS, Smith JL. Advanced nutrition and human metabolism. 4th edition. Wadsworth, USA: a division of Thomson Learning, Inc; 2009.

8. Broek NR, Letsky EA. Etiology of anemia in pregnancy in South Malawi. American Journal of Clinical Nutrition. 2000; 72 (suppl): 247S-56.

9. Ekstrom EC, Hyder SM, Chowdhury AM, Chowdhury SA, Lonnerdal B, Habicht JP, et al. Efficacy and trial effectiveness of weekly and daily iron suplementation among pregnant woment in rural Bangladesh desentangling the issues. American Journal of Clinical Nutrition. 2002; 76: 1392400 .
10. Yetley EA. Multivitamin and multimineral dietary supplements: definitions, characterization, bioavailability and drug interactions. American Journal of Clinical Nutrition. 2007; 85 (1): 269-76.

11. Morris MS, Jacques PF, Rosenberg IH, Selhub J. Folate and vitamin B12 Status in relation to anemia, macrocytosis and cognitive impairment in older American in the age of folic acid fortification. American Journal of Clinical Nutrition. 2007; 85: 193-200.

12. Sahyoun NR, Pratt CA, Anderson A. Evaluation of nutrition education intervensions for older adults: a proposed framework. Journal of American Dietetic Association. 2004; 104(1): 58-69.

13. Sandstrom B. Micronutrient interactions: effect, absorption and bioavailability. British Journal of Nutrition. 2004; suppl 2: S181-5.

14. Nasution E, Lubis HS. Hubungan konsumsi zat besi dan status gizi dengan produktivitas kerja wanita pencetak batu bata di Kecamatan Pagar Merbau. Jurnal Info Kesehatan USU. 2005; 9(2): 4-8.

15. Florentino RF, Tanchoco CC, Rodriguez MP, Cruz AJ. Interactions among micronutrients deficiencies and undernutritions in the Philippines. Asia Pacific Journal of Clinical Nutrition. 2006; 5(3): 175-80.

16. Rizkiawati. Faktor-faktor yang mempengaruhi kadar $\mathrm{Hb}$ dalam darah tukang becak. Jurnal Kesehatan Masyarakat Undip. 2012; 1(2): 27-31.

17. Hidayat. Hubungan asupan protein, $\mathrm{Fe}$, dan vitamin $\mathrm{C}$ dengan kadar $\mathrm{Hb}$ dan daya tahan jantung para atlet pada pemusatan pelatihan daerah Pra PON XVII Provinsi Daerah Istimewa Yogyakarta. Jurnal Poltekkes Yogyakarta. 2012; 8(1): 2-5.

18. Ramakrishnan U. Nutritional anemias. CRC Press: Boca London; 2004. 